\title{
The Costs of Legal Limbo for Refugees in Canada: A Preliminary Study
}

\author{
Tim Coates and Caitlin Hayward
}

\begin{abstract}
This paper is designed to provide a preliminary understanding of the barriers facing refugees in legal limbo in Canada. In particular, it will focus on the economic implications, for both protected persons and Canadian society at large, of maintaining tens of thousands of individuals in this difficult situation for extended periods of time. The findings are preliminary, and designed to indicate future avenues of research, as well as potential roadblocks to research in this area. The paper also includes some of the results of a survey of Convention refugees and the refugee-supporting organizations, conducted by the Public Justice Resource Centre. The initial conclusions indicate that the costs of limbo are large enough to warrant serious reconsideration of this stage of Canada's refugee determination policy. The rationale for this study was to help key decision makers see the futility and the unnecessary cost to the government of keeping refugees in limbo.
\end{abstract}

\section{Résumé}

Cet article vise à fournir une compréhension initiale des obstacles confrontant les réfugiés qui se retrouvent dans un état juridique indéterminé au Canada. Il se penchera en particulier sur les implications économiques à la fois pour les personnes protégées et la société canadienne en général de garder des dizaines de milliers d'individus dans cette situation difficile pendant des périodes étendues. Les résultats sont encore préliminaires et sont conçus pour indiquer les voies de recherche pour l'avenir, aussi bien que les obstacles possibles à la recherche dans ce domaine. L'article propose aussi des extraits des résultats d'un sondage effectué auprès des réfugiés et d'organismes de soutien aux réfugiés par le Public Justice Resource Centre (Centre de ressources pour la justice publique).
Les conclusions initiales indiquent que les coûts de cet état indéterminé sont suffisamment élevés pour justifier une sérieuse remise en question de cette étape dans la politique de reconnaissance des réfugiés. Le raisonnement pour entreprendre cette étude était d'aider les décisionnaires-clés à voir la futilité et le gâchis superflu de garder les réfugiés dans un état indéterminé.

\section{Preface}

Dleeing the devastating consequences of twenty years of 4 civil war and the repressive Taliban regime, Khalida fled to Canada from Afghanistan in early March $1999 .{ }^{1}$ To Khalida, Canada was a utopia of hope and as a refugee she wished to forget her past, start fresh, and be reunited with her children who had fled the year before and were staying with family in Toronto. But for Khalida the benevolent and welcoming Canada she expected has not been the country she experiences. ${ }^{2}$

In night I sometimes can not sleep and I just walk and walk around the lobby [of my apartment building]," she says. Her stress is palpable. She is not old but frail from the stress that characterizes her eyes and marks her face. Khalida is a Convention refugee and has applied for permanent resident status in Canada with her husband also on her application. When she is granted status her husband will be able to join them in Canada. However, it has been four years since she was granted Convention refugee status, much longer than official timetable of six to twelve months for determining status stated on the Citizenship and Immigration Canada Web site. She has not heard from the government officer assigned to her case in six months. When she does hear, they repeat a mantra now all too familiar to the family - they are waiting on security checks.

They are "not giving any response, but we need our dad as soon as possible," Khalida's daughter and oldest child tells me. His absence is a large part of our conversation and 
obviously has a depressing effect on the family's mood. "The stress of my mom is being too much for us and it is because my dad is not here," the daughter continues. "One person is supposed to stay with my mom but I can't because I have to work." Khalida concurs, "I can no longer take care of my children when they're missing all the time their father. They need their father. Even sometimes my family asking 'where is he' and other kids at [my children's] schools are asking."

The situation of Khalida and her family is not uncommon in Canada. Over twenty thousand Convention refugees like her are awaiting permanent resident status, or what used to be called "landed immigrant" status. They are unable to get on with their lives while issues relating to criminality, security, and identity documents are sorted out. In the process, the government spends millions of dollars unnecessarily. For refugees, for the government and therefore the Canadian taxpayer, it is a lose-lose situation. During this stage in their refugee determination process, refugees are in limbo. They are withheld rights that Canada must provide under its international obligations. Refugees encounter barriers to employment, mobility, training programs, and access to adequate health care and democratic rights, ones that someday will eventually be theirs since refugees may not be removed from Canada.

\section{Introduction}

This paper was designed to provide a preliminary understanding of the barriers facing refugees in legal limbo in Canada - those awaiting, often for years, permanent resident status. In particular, we wished to focus on the economic implications, for both protected persons and Canadian society at large, of maintaining tens of thousands of individuals in this difficult situation for extended periods of time. Such research would provide an important element of a broader argument, most frequently articulated on humanitarian grounds, that suggests that the costs of limbo are large enough to warrant serious reconsideration of this stage of Canada's refugee determination policy. The rationale for this study was to help key decision makers see the futility and the unnecessary cost to the government of keeping refugees in limbo.

As of 2003, there were over 16,200 cases of refugees in "limbo," involving almost 22,000 people. ${ }^{3}$ For many refugees, limbo in Canada is not a short-term affliction. While there is no official statistic from Citizenship and Immigration Canada (CIC), several people in the refugee support community have stated that the current wait is at least eighteen months. ${ }^{4}$ A variety of factors contribute to a significantly longer waiting period. Some refugees interviewed for this study have been in limbo for eleven, twelve, even thirteen years.
This study is a preliminary attempt to compare the costs and benefits to Canada of keeping refugees in limbo. This, as we anticipated and subsequently confirmed, is very difficult to quantify. Cost studies in general are complex; they demand sophisticated technical skills and training in methodology and economics. Attempts to quantify social and economic phenomena often require assumptions so that information fits reality. This study is built around the assumption that being trapped in limbo directly and indirectly creates extra costs and it is possible to quantify barriers to refugee integration. These were found through interviews with settlement agencies and our Convention refugee questionnaire. At this point an important caveat needs to be added: The economic costs to Canada found in this study are above what would normally be incurred through the refugee determination system, without an extended period of limbo as currently exists.

Our findings point to clear evidence of significant costs both to Canada as a whole and to refugees themselves who are left in legal limbo. The difficulty of obtaining information, however, makes this a preliminary study which will require further work should a policy change not be forthcoming.

This paper is divided into four sections. The first part will review the state of refugees in Canada and how the process for In-Canada Refugee Protection operates, what has changed since September 11, 2001, and how these changes open a window of opportunity for necessary policy changes. Section two briefly discusses our research methodology and outlines gaps in the literature of economic research in refugee issues. During limbo, refugees face many barriers to integration. These will be analyzed in the third part, while the final section presents the economic costs these barriers produce.

\section{Part 1. Refugees: Yesterday and Today}

Canada has a reputation as one of the most "refugee friendly" of all the world's nations, with innovative programs and compassion for the displaced. In 1986, UNHCR awarded Canada the prestigious Nansen Medal (the only occasion in which it has been given to a country), for its "major and sustained contribution to the cause of refugees." Since World War II, nearly a million refugees have found a new home in Canada.

While a majority of Canada's history with non-Western European immigration has been marked by high barriers and racism, policies and attitudes changed in the late twentieth century. Large changes occurred with the emergence of the Immigration Act in 1976. Selection criteria for independent immigrants were broadened while refugees were identified as a separate class from immigrants. The Immigration and Refugee Board was created in 1988 to review claims of refugee claimants and select them based on estab- 
lished criteria. More recently, since September 11, 2001, and the Immigration and Refugee Protection Act (IRPA), which came into force on June 28, 2002, sweeping changes have been made to the asylum determination procedures, the impact of which is still to be assessed. One of the most troubling of IRPA's features is the greatly expanded powers granted to authorities to detain foreign nationals without a warrant if there's "reasonable grounds" to believe the person is a threat to the public. ${ }^{5}$

\section{IRPA and September 11, 2001}

Canadian immigration and refugee policies have come under intense scrutiny in the aftermath of September 11, 2001. Many American officials and media outlets have pointed fingers at Canada, accusing Canada of being soft on terrorism and stating that its immigration and refugee policies are gifts to terrorists trying to enter the U.S. ${ }^{6}$ Even Canadian Daniel Stoffman, in his book Who Gets In, says, "Canada is indeed a terrorist threat, both to itself and to its neighbors."7 He quotes an American immigration think-tank, saying, "Terrorists from all over the world have been using Canada's asylum system... You can come in [to Canada] with no documents, or fake documents, and say you want asylum and they let you in."8

This is the harsh environment refugees encounter when arriving in Canada and the politics refugee workers must sift through in order to do their job. However, any serious analysis of the refugee determination system will find that it does not pose any terrorist threat. A 2001 report prepared for Citizenship and Immigration Canada on undocumented refugees found that out of a group of 2,161 undocumented persons who applied for permanent resident status, only one failed the criminal check. ${ }^{9}$ Only one involved a person with crimes sufficient to warrant a denial of landing. ${ }^{10} \mathrm{~A}$ further discussion on the images and portrayal of refugees post-September 11 is beyond the scope of this paper. However, it is worth quoting a passage from a recent piece by Howard Adelman at length:

It is clear that terrorism aimed at North America is a real threat and both aggressive and defensive measures must be taken to combat it. Though some of those defensive measures include enhanced immigration controls, there is virtually no evidence linking global terrorism with refugees. ... There is even more evidence that the security threat - which is real and palpable has been used as a cover to cut down on the entry of refugee claimants coming to Canada whether through visa controls or through the proposed implementation of a safe third-country system. If there are justifications for this indirect cutback by greater restrictions on access to the system, one of them is not security; the security issue is a rationale rather than a reason. ${ }^{11}$

\section{Refugee and Protected Persons in Canada}

Two types of refugees are recognized by Canada. Those sponsored overseas by the government or a private group and brought to Canada are called "resettled refugees," and are granted permanent residency (formerly known as landed status) immediately upon arrival in Canada. The second group, those individuals who go through the inland refugee determination system, are those who enter Canada by land, sea, or air and claim asylum from persecution. Under the IRPA, the latter group is included in the new category of "protected persons," which includes, but is not strictly limited to, Convention refugees. For the purposes of this article, we are concerned with people whose refugee claims have been accepted in Canada but who have not yet achieved permanent resident status. The following is a brief summary of the refugee determination system. ${ }^{12}$

Upon arrival in Canada, the refugee claimant makes a claim at a border point or from within Canada for asylum. Citizenship and Immigration Canada receives the claim and decides within three days whether or not the claimant is eligible. Claimants for asylum in Canada are not eligible if they:

- are found to have made a refugee claim in Canada before;

- are recognized by another country as a refugee;

- came to Canada through a "safe third country";

- have been determined to be inadmissible because of security, criminality, organized criminality, or violating human or international rights.

If eligible, the claimant is referred to the Refugee Processing Division (RPD) of the Immigration and Refugee Board (IRB) and has twenty-eight days from the time of the claim to complete and send a Personal Information Form (PIF) to the IRB. The IRB is an independent quasi-tribunal that hears and makes a determination with regard to the credibility of a claim for refugee status.

A claimant accepted by the IRB becomes a protected person and can apply for permanent residence. A claimant refused by the IRB can apply for judicial review to the Federal Court and also for a Pre-Removal Risk Assessment. This study is concerned only with those claimants accepted by the IRB and hence deemed protected persons. They now enter a state often referred to as "legal limbo." They may have peace of mind in knowing they can not be sent home and enjoy more rights and opportunities as claimants, but face numerous obstacles and delays prior to enjoying the rights and privileges of permanent residents.

As stated above and explored further below, without permanent resident status, refugees must endure unnecessary hardships. The Canadian Council of Refugees (CCR) identifies three main reasons why Convention refugees can experience long delays in waiting to become permanent residents. ${ }^{13}$ 
1. Identity documents.A legislative amendment introduced in 1993 requires Convention refugees to produce "satisfactory identity documents" before they can be granted permanent residence. The lack of identity documents for Afghanis and Somalis helps explain why many of them remain in legal limbo. Citizens of Sri Lanka have also been heavily affected: indeed, Convention refugees from Somalia, Sri Lanka, and Pakistan combine to make 36 per cent of all refugees in limbo (see box 1.1). To accommodate the growing number of refugees without IDs, undocumented claimants arriving in Canada can use section 178 of the IRPA regulations, which allows statutory declarations that attest to a person's identity to replace the need for presenting an official ID.

2. Fees. Refugee claimants can expect to pay significant fees in order to become permanent residents. Since 1994 all Convention refugees must pay a $\$ 550$ processing fee per adult and $\$ 100$ per child.

3. Security Checks. After passing the IRB, a Convention refugee's background is checked again before being approved for permanent residence. The Canadian Security Intelligence Service (CSIS) and the Royal Canadian Mounted Police (RCMP) perform background checks using different systems, and must also coordinate with officials in the originating country as well as those in any other country of previous residence. Performed on different systems and largely uncoordinated between organizations, security certificates expire every eighteen months, and must be revalidated after this time, amounting to more delays.

These security checks are an exact repeat of what now occurs at the point of making a claim and the IRB determination process. They are effectively redundant. In any case, there are methods available to the government should a recognized refugee or permanent resident be found to have lied on their original application or be otherwise deemed ineligible. Under the IRPA and the Citizenship Act, the Minister can revoke both permanent resident and refugee status, providing effective safeguards for mistakes earlier in the system. ${ }^{14}$

Several other reasons can lead to limbo delays, including pressure from the system itself. If a refugee fails to apply for landing within 180 days of being granted Convention refugee status (with the accompanying $\$ 550$ fee) they then may apply for permanent residency only under the humanitarian and compassionate stream $(\mathrm{H} \& \mathrm{C})$ of the immigration procedure - where documentation guidelines and other conditions are much more stringent.

\section{Part 2. Methodology and Research Notes}

\section{Refugee Economics}

Immigration issues have been a frequent topic of academic, policy, and political studies and discussions; nevertheless,
Box 1.1

Origin Country of Limbo Refugees in Canada 2002

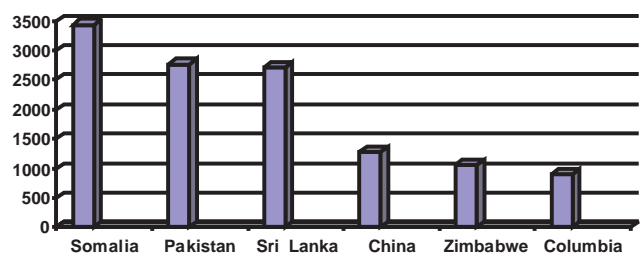

there is a surprising dearth of economic studies concerning refugees. While it is a topic of frequent political and media discussion, the economic impact of refugees has been infrequently and unevenly studied. ${ }^{15}$ This may be due to the scarcity of quantitative and statistical information concerning refugees. The Canadian census, the most regular and comprehensive source of data, does not distinguish between immigrants and refugees, leading to the frequent "lumping together" of these two groups for the purposes of academic and policy studies.

Another problem with studying this topic is that much of the current research does not focus on the impact of protected persons on host countries. Most studies do not distinguish labour migrants, family migrants, and resettled (overseas determined) refugees from protected persons (including Convention refugees). A recent American study points out that most of the economic integration and impact research in Canada, the U.S. and Australia focuses on resettled refugees, "with little attention to the experiences of those entering through the asylum system."16 There are, however, studies that analyze trends and economic consequences of immigration. These studies provide a broad picture of the effects immigration has on host countries in term of per capita output (small net gains but their distribution may be uneven), unemployment (no impact), and impact on government expenditures and revenues (negligible). ${ }^{17}$ Refugees are included in these analyses but their specific impact is unknown and most likely an extremely small factor. In any given year "in Canada" refugees compose a very small proportion of total immigration. In 2001, refugees represented 12.5 per cent of total immigration. Over the past decade this number has fluctuated slightly but remained between 9 and 15 per cent: a very small population. ${ }^{18}$

The most thorough example of research on the impacts of refugees vis-à-vis other forms of migrants on receiving countries, conducted through the United Nations University, discusses the factors that determine the impact of asylum, as distinct from other forms of migration, and 
discusses factors such as the number of asylum seekers/refugee claimants, government policies, and socioeconomic characteristics. As might be suspected, their conclusions suggest that the impact differs depending on the country involved and their respective policies. ${ }^{19}$ Government policies for determining refugee status impact the host countries in various ways. If policies are complex with many administrative layers, fiscal costs increase. The impact of refugees will vary depending on the skills and on the socio-economic and demographic characteristics of claimants and Convention refugees. The level of integration into the host country (including issues such as work permits; access to social welfare programs, including health and financial aid; education; and language training) will also significantly change the picture. The authors conclude that: "depending on the nature and effectiveness of some of the policies, those granted asylum or complementary protection may become quickly selfsupporting or languish for lengthy periods of time on public assistance." 20

\section{Methodology}

The lack of quantitative research in refugee issues presented several problems for this study. As a result, after a broad literature review and focus on academic and governmental information, a survey for Convention refugees was designed and interviews conducted with selected refugees as well as with various settlement agencies located in Toronto, Ontario, during July and August of 2003.

\section{Interviews}

Approximately 60 per cent of all newcomers to Canada settle in the Greater Toronto Area (GTA). Much of the support these newcomers receive comes from a pre-existing community of immigrants and refugees in Toronto, as well as multicultural and faith-based organizations. These settlement agencies have specific programs to assist new immigrants and refugees integrate into Canadian society and have knowledge of the obstacles faced by refugees during their first few years in Canada. Our primary researcher met and interviewed either the executive director or the director of settlement services of fifteen settlement agencies in the GTA. The interviews served to gain a more in-depth understanding of problems in integration faced by Convention refugees as a whole.

\section{Refugee Survey}

The survey was sent to, and completed by, Convention refugees from each region of Canada and from various countries of origin. While there are other types of limbo that exist, this study is focused on Convention refugees who have not yet been granted permanent residence in Canada, and so is limited to those who meet that criterion. Many refugees were located with assistance from the settlement agencies with which the interviews had been conducted. As predicted, most of the surveys were completed by those persons who have been in limbo for a considerable period of time.

Surveying began in early July 2003 and ended in August 2003. Both snowballing and cold calls were used to connect with Convention refugees. Surveys were answered by personal interviews with the researcher or settlement worker and via phone interviews. Attempts were made to match survey respondents with national refugee demographics. After the first week the survey was updated, refined for clarity, and translated into French and Spanish.

\section{Research Findings}

Interviewing refugees poses unique challenges that include language barriers, fear that information could be used against them, and misunderstandings. We also encountered more general difficulties. We had to discard about ten surveys because they were not properly completed. For reasons of time as well as in the interests of broader results, volunteers were used to conduct the survey. While we attempted to brief everyone in a similar way, there is little doubt that this affected results.

With a response rate of between 30 and 40 per cent, fifty-eight surveys were completed. Given the preliminary nature of this research, we were pleased with these results, but realize that in order for the conclusions to be used more broadly, a larger sampling needs to be done.

There were also some research and data sets that we did not receive for various reasons. Questions about the average time spent in limbo remain unanswered: our survey suggests slightly over four years. However, there were a large number of Somalis in our survey group; as a group, their lack of documentation places them at an increased risk for longer periods in limbo. Citizenship and Immigration could not provide us with their statistics, nor with information on how many refugees use the "Aden Agreement declarations" (now section 178 of the IRPA regulations) for landing purposes, which may increase time spent in limbo.

Perhaps the most frustrating part is the lack of appropriate data collection by Statistics Canada and other data organizations. The distinction between" immigrants" and "refugees" is not consistently used, forcing researchers into generalizations and suppositions. Particularly in a field marked by rhetoric and a significant amount of confusion among the general public, consistent and accurate data would go far in increasing understanding amongst all involved. 
The preliminary results below are based on our interviews and the limited other information currently available. It creates a framework for further, more detailed research.

\section{Part 3. Barriers to Integration}

The central concern that informs this research is the cost of keeping people in the category of protected persons for an extended period of time prior to granting them permanent residence. This section will briefly look at some of the major areas in which this limbo impacts the Canadian public, including the impact on "Canadians-in-waiting" - protected persons. The purpose is to provide some preliminary findings and to delineate areas for further research of the economic costs and benefits of this element of the refugee system in Canada.

As previously stated, protected persons have more rights in Canada than do refugee claimants, but are also marked by particular restrictions and barriers usually absent from the experience of permanent residents and citizens. The authors of this paper argue that these barriers - which affect areas as diverse and important as employment, mental health, finances, and personal privacy and security - are detrimental to both the individual refugee and host country.

Barriers manifest themselves in various forms. Some are the result of deliberate policies regarding protected persons, designed and implemented by the various levels of government. These include financial, personal, and social restrictions. Protected persons cannot sponsor family members overseas and are faced with particular mobility restrictions. In the same vein, they are not eligible for various government and social services, including domestic tuition rates at universities and colleges in several provinces. Other types of impediments are not in themselves policies, but are the foreseeable and negative consequences of immigration decisions that have been aggravated by the increasing time spent in limbo. Chief among the latter are employment and health concerns; while it is illegal, there is some evidence to suggest that protected persons are subject to exploitation by less-than-scrupulous employers, who are aware of their somewhat precarious situation..$^{21}$ The strain of limbo, in particular family separation as well as the stresses of seeking refuge in a foreign country, is also a considerable factor in relation to mental and physical health. Protected persons are ineligible for bank loans and various other forms of credit, while simultaneously being required to raise money to pay their landing fees.

\section{Labour Market}

Labour market barriers are the easiest to identify and also the most important for successful integration into Canadian society. In 2002, Citizenship and Immigration Deputy
Minister Michel Dorais wrote that newcomers to Canada "experience difficulty entering the labour market. The absence of effective credential assessment and recognition process, as well as insufficient supports for work related language training, contributes to the gap between immigrant earnings and employment rates and those of Canadian-born workers." 22 Dorais recognizes that having the ability to work in Canada is the most important way to integrate into Canadian society.

For Convention refugees, finding work can be extremely difficult and frustrating. Many factors impede refugees from having the same access to employment as permanent residents and citizens, so many settle for low-paying, service industry positions. Racism, stereotypes, lack of training opportunities, language, work ethic misconceptions, and a 900 -series Social Insurance Number (SIN) ${ }^{23}$ all are impediments to employment. ${ }^{24}$ Certain jobs are out of reach because the necessary licensing (i.e., for truck drivers) is only available to permanent residents and Canadian citizens.

If I have landing I have better job, life will be much different. Always have problem with my children, for their summer vacation they like to go on vacation but I have no vacation and must work...I'm fed up with CIC...my kids are always asking when I will get my landing. I send lots from my lawyer and many different letters, [I'm] always doing something, do medical check, do this, do that but always same, never landed. - A Somalian Convention Refugee

The most thorough study done on this subject to date came from the University of Alberta, which surveyed 525 refugees and their experiences in Alberta between 1992 and 1997. It found major employment barriers that included limited English language skills, discrimination on the part of employers, lack of Canadian work experience, and an unwillingness on the part of professional bodies to recognize foreign training or work credentials. Interestingly, professionals, the most skilled and educated of all refugees, faced the most austere barriers from licensing bodies like the Canadian Medical Association, which would not recognize their credentials. Three out of four Convention refugees were not able to obtain managerial/professional employment after coming to Canada. ${ }^{25}$

The conclusions of the University of Alberta study are very instructive about conditions refugees face upon arriving in Canada. According to the study, "refugees are also much more likely than the Canadian workforce as a whole to be employed in non-standard jobs, which typically pay less, offer fewer fringe benefits, and have much less job security." ${ }^{26}$ Many refugees need training programs to improve upward mobility. Presently these are available 
through the government for Canadian citizens and permanent residents only.

\section{Family Reunification}

Convention refugees who have not been landed are not able to sponsor spouses or dependent children to Canada until they themselves become permanent residents. A united family gives the refugee further support to cope with the stresses of resettlement and an increased flexibility to adjust to a new country and culture. Khalida (see preface) is a perfect example of the effects of family separation gone too long. She and her children have not seen their husband and father for six years. She is ill from the compounded stress of adapting to a new country, single parenting, financial problems, and anxiety concerning her spouse in Afghanistan. Her health has deteriorated to the point where she needs assistance with simple day-to-day activities.

\section{Mental Health}

This separation of family leads to another major problem area facing the refugee community - mental health. One of the tenets of mental health is that a period of rapid and significant change places increased strain on an individual's mental health. ${ }^{27}$ In a letter to the editor in the Toronto Star, Alejandro Ferrino wrote that:

...during the past 13 months, my Argentinean wife, whom I married in Toronto in 1999, and I have had to deal with emotional stress and economic struggles as we performed a number of steps required for her to become a resident. The waiting period became a nightmare full of anxiety, anguish, irritability, apathy and frustration...to be left in limbo seems an arbitrary price to pay. ${ }^{28}$

One worker from an ethno-racial mental health centre estimated that 90 per cent of all refugees experience anxiety, stress, distress, or depression. ${ }^{29}$ However, it is important to recognize that the assumption that the entire refugee population is mentally disturbed and in need of psychiatric care needs to be avoided. Many refugees are very resilient and adaptive and have managed to navigate the refugee process without requiring significant aid from mental health networks.

If I look over the general criteria to diagnosis Mental disorders - Dissatisfaction with one's characteristics, abilities and accomplishments, ineffective or unsatisfactory relationships, dissatisfaction with one's place in the world or confusion coping with live events and lack on personal grown - I see I was mental illness. Example when people talk to me about what matters I start crying. I could not have any long conversation with any body because the teardrops came out. - Refugee in New Brunswick]

In a recent article regarding refugees and resettlement, Dr. Ralph Masi, founder of the Canadian Council of Multicultural Health, notes that:

There are issues specific to particular ages and genders. Young people may have difficulty fitting in with peers because they speak differently or lack the same cultural reference points....Women and seniors may face a loss of independence and social support structures. ${ }^{30}$

By virtue of their status as someone seeking refuge, refugees are likely to have experienced trauma and extreme stress, which may place them at a higher risk for mental health problems. They may be in need of professional treatment but seeking and finding a physician or psychiatrist to work with refugees presents particular difficulties. While there remains a persistent stigma attached to seeking counselling and mental health care within Canadian society at large, there are also specific concerns, such as language barriers, cultural norms, and a fear of jeopardizing the immigration process, which can make it more difficult for protected persons to seek the necessary help. The timing is also important: the mental health agency with whom we spoke only saw cases where the mental health effects had become debilitating to the individual. Help sought earlier may have decreased the seriousness of the symptoms and of the care necessary.

Yet remarkably, a study conducted for the Centre for Addiction and Mental Health found no evidence to confirm the expectation that refugees were at a higher risk for mental health problems due to their experiences prior to arrival in Canada. It concluded that "while the refugee situation undoubtedly creates a situation of risk for mental health, risk is not destiny." ${ }^{11}$ Experiences that occur prior to arriving in the new country have a smaller effect than what happens to refugees during resettlement. Being trapped in limbo and separated from family, possessing inadequate language skills, facing employment discrimination and discrimination from Canadian nationals pose a greater risk of developing future mental health problems than their experience of fleeing persecution. ${ }^{32}$

\section{Mobility}

Convention refugees are not afforded Canadian passports, and undocumented persons are often denied travel documents. This effectively prevents refugees from travelling 
abroad to visit family members. Given that many refugees in Canada send money abroad to support family members, contact between family members in these situations is critical to be sure money is being received and that they are healthy. The CCR notes that even when a family member is sick and dying, travel documents can be difficult to obtain. ${ }^{33}$ Refugees may also fear they will be refused entry to Canada on their return. Under new regulations, permanent residents are given a permanent resident card, a standard and "normalized" document which serves as a substitute for a Canadian passport. This is the card and status for which refugees in limbo are waiting.

\section{Political Rights}

Only Canadian citizens are entitled to vote in Canada. As the time between the granting of protected person status and permanent residence increases, so does the time between arrival and full citizenship rights. Such rights are pivotal to the development of refugees as new Canadians: as Nobel Prize-winning economist Amartya Sen states in his book Development as Freedom, political freedom arises with the right to vote. "The rulers have the incentive to listen to what the people want if they have to face criticism and seek their support in elections. Political rights... are not only pivotal in inducing social responses to economic needs, they are also central to the conceptualization of economic needs themselves." ${ }^{34}$ By lengthening the period in which individuals are denied meaningful participation in the political system, we may also be increasing the risk that these people will remain removed from such participation, even as full citizens.

\section{Landing Fee}

As mentioned in the first section, protected persons are required to pay a $\$ 550$ landing fee for each adult seeking permanent residence, and $\$ 100$ for each dependent child. While these costs may not appear prohibitive to many settled, employed, and fully entitled citizens, they present an early and serious obstacle to the landing process. Refugees are not eligible for bank loans and credit cards, as well as various other forms of credit, making access to large sums of money - needed for the landing fee as well as furniture, rent, transportation, clothes, and other necessities - difficult.

\section{Security and Medical Checks}

Security and criminality checks performed by CSIS and the RCMP, as stated above, are uncoordinated. Each check is performed separately and each organization works with different organizations overseas. If and when CSIS sees something incongruent, flags are raised and the process can stretch from weeks to months, even to years. The RCMP also wants a second set of fingerprints - already taken during the front-end screening process - for a separate criminal database.

Medical certificates and security checks can play an insidious game of cat and mouse, leaving the Convention refugee trapped in a cycle. Medical checks expire after twelve months while Security checks expire after eighteen. Often the medical will expire before the security process is complete. The medical will have to be redone only to have the security check expire. This cycle can be very frustrating as well as potentially confusing, leading to increased risk of mistakes and bureaucratic delays.

\section{Procedural Changes and Discretion}

There has been significant criticism of the Canadian refugee determination process from many fronts, some of which was addressed with the new IRPA legislation. However, there remain many areas in which the discretion of one individual, employed either by the Ministry of Citizenship and Immigration or the IRB, can delay or severely stall the landing process. While the system designed under the IRPA has some measures to counteract this, several of them (including the refugee appeals board for the IRB) have not been implemented. The number of changes which has occurred over the past few years has also increased confusion within the system, felt by government officials, advocacy and legal workers, settlement agencies, and the refugees themselves.

\section{Part 4. Economic Impacts}

The flip side of finding the economic impacts to Canada of keeping refugees in limbo is the direct cost of Canada's refugee determination system. Again, due to lack of full information available, these findings are preliminary.

\section{Labour Market}

Costs to Convention refugees in limbo due to barriers in the labour market are the easiest to quantify. Refugees discriminated against or limited because of legal status incur opportunity costs of labour. The Conference Board of Canada has completed the best research in this area with a study entitled Brain Gain: The Economic Benefits of Recognizing Learning and Learning Credentials in Canada. This study focussed on three groups who would gain the most if their learning credentials were recognized, with immigrants being the largest group. Their major finding is that, if Canada were to eliminate the learning recognition gap, it would give Canadians an additional $\$ 4.1$ to $\$ 5.9$ billion in income annually. ${ }^{35}$ From this study, which makes no distinction between immigrants and refugees, we can deduce an estimate of forgone income due to unrecognized learning for refugees. 
The authors of the Brain Gain study estimated that the number of people in Canada that are affected by unrecognized foreign credentials equates to 344,723 people. In order to provide a rough picture of the lost earnings for refugees in limbo, we assumed that refugees follow Canadian employment characteristics. ${ }^{36}$ Based on the number of refugees in this state, and applying the estimate of forgone earnings to the figures, results in an overall estimate of potential earnings from reducing the barriers of limbo of over \$334 million dollars.

\section{Social Assistance}

In terms of social assistance, there is a large difference between immigrants and refugees, as the former have more choices in terms of employment and mobility. For statistical purposes, as Convention refugees move through the system and gain landed status, they are grouped with immigrants as the legal status of the two converges. A great deal of information can be deduced by comparing the situations of immigrants and Convention refugees. Our survey asked Convention refugees what government services they used while in limbo. By far the most frequent response was welfare with 81 per cent having received social assistance for at least one month. Most refugees reported being on welfare prior to being deemed a Convention refugee, as well as afterward. However, there is a drastic drop in the numbers once landed status has been gained, with only 17 per cent of all immigrant families receiving some form of government assistance. ${ }^{37}$

To measure welfare spending by the government on Convention refugees, average annual rates of government transfers to Convention refugee households were found. The proportion of Convention refugees on welfare, 81 per cent, was then used to measure the total number of limbo refugee households on welfare and multiplied through by the annual average each household receives. The monetary figures that correspond to this are staggering. According to our survey, Convention refugees in 2002 received an estimated $\$ 129,115,689$ in welfare payments. ${ }^{38}$ Assuming 17 per cent of immigrant households remain on government assistance, the number of cases in Canada was divided by 17 and multiplied by average social assistance payments. This found that after refugees are landed, their welfare needs decrease substantially to an estimated total of $\$ 27,437,084$, a savings of over $\$ 101$ million dollars.

\section{Mental Health}

As discussed in the previous chapter, protected persons face a variety of stresses that can affect their well-being and place them at risk of mental health problems. Nevertheless, based on the lack of research (also previously discussed), it is difficult to ascertain the costs of this increased risk. The estimated total burden to Canada of mental health problems is among the costliest conditions in Canada at \$14.4 billion. ${ }^{39}$ However, information specific to the refugee situation is not available. Research to estimate an accurate refugee-specific economic cost is beyond the scope of this paper and is an area where further research is sorely needed.

\section{Administrative Costs}

Accurate estimates of the costs of the refugee system itself are hard to find. Not knowing an accurate breakdown of costs within the refugee determination system has been problematic for this study. Several pieces of information critical for a rigorous analysis are simply not available. Public data collection capabilities need to be improved for further research.

To begin to quantify the administrative costs of keeping seventeen thousand or more case files in the system for periods as long as a decade is formidable. A study of this nature would require significant research and the collection of mass data as well as its analysis, which is not available for this project. However, it seems safe to assume that in terms of government effort, there would be a significant cost, both in terms of human resources and budget, involved in keeping all of these files current.

\section{Conclusion}

Canada has traditionally been one of the most welcoming countries in the world for refugees. However, this reputation is quickly eroding in the post-September 11 era, being challenged by changes to Canada's immigration policy and heightened global and national security concerns. The number of refugees landed in Canada is declining every year - from 12,991 in 2000 to 10,544 in 2002 - and this will certainly continue if Canada and the U.S. implement the Safe Third Country agreement. ${ }^{40}$ A July 2003 BBC news report said, "it seems Canada is moving more towards, rather than away from, a stricter system like Australia's, in which civil servants decide claims and more people will be detained." ${ }^{41}$

Convention refugees in Canada experience long delays in achieving permanent resident status. During this time they experience many impediments blocking integration into Canadian society. Direct barriers are felt in the labour market where quality employment is difficult to find. Refugees cannot open bank accounts or gain access to credit while some Convention refugees cannot afford the necessary fees. Indirect effects include a deterioration in one's mental health caused by needing to adjust to a new culture and dealing with family separation and/or poverty.

Economic research with regard to refugees is difficult to find. Most importantly, we tried to find the cost of main- 
taining a refugee system in Canada. While we could not find an actual figure, there is a strong and general perception in Canada is that it must be very high, maybe even too high. In his book Who Gets In, nominated for the annual Donner Prize for best book on Canadian public policy in 2003, Daniel Stoffman claims that Canada's refugee program "no doubt accounts for a major portion of the $\$ 4$ billion-a-year cost of immigration..." ${ }^{22}$ Unfortunately, this figure can't be sourced to any government publication. Even more disconcerting is how the statement misleads readers into thinking that the only associated costs are government expenditures. We hope this study alters this parochial way of thinking. This research finds that there are other costs related to the refugee determination system. A process that hinders refugee integration poses undue costs to Canada in the form of suppressed labour market activity, debilitation from mental duress, excessive use of social assistance, and other barriers. An effective and efficient system will greatly mitigate most of these costs.

Our preliminary research estimates show that Canada's refugee system is highly inefficient and likely impedes refugee integration. We find that Canada spends over an estimated \$129 million on government transfers to Convention refugees in limbo. With automatic landing, government transfers would decrease dramatically with an estimated savings of over $\$ 101$ million. Our research also finds that refugees lose over $\$ 334$ million in forgone income due to barriers in the labour market. Racism, stereotypes, lack of training opportunities, and language are all impediments to employment. These large costs only account for two barriers, albeit two larger ones. Further study into the economic costs of these and other barriers is an area in dire need of attention.

Our findings and estimates were limited by resources, timeframe, and information availability. A more thorough investigation, unhindered by these factors, is required for a clearer picture of the economic costs of delaying landing for refugees. A more rigorous analysis would ideally include several reports on the economic consequences of specific barriers. For example, mental health problems in refugees are extensively studied by psychologists and psychiatrists but rarely with an economic focus. The refugee community is sorely in need of this type of research to buttress their arguments and to refute some of the anti-immigrant, antirefugee claims in the media.

The lack of research into Canada's refugee system prevents the dissemination of information that could bolster arguments made by Canada's refugee community, that immigration is a boon, or at the very least, entails zero cost to Canada. Canada's refugee community draws largely on moral and legal arguments for advocacy but there is a need for a different perspective. Economic studies have proven to be a very effective means of garnering attention to issues (for example, poverty and its effect on the health care system) and we hope this study provides a similar impetus for refugee issues. This research can be used as a springboard for such further research.

To our knowledge this study is the first attempt to place an economic value on a particular aspect of Canada's refugee determination system. Being the initial study, several issues were encountered that should be discussed. One of the reasons refugee research may not be prevalent could be the poor condition of data sources. As mentioned earlier, Statistics Canada does not separate refugees from immigrants in their data tables. Citizenship and Immigration Canada has basic information on the number of Convention refugees entering Canada annually but nothing more detailed.

Through our research we found that Convention refugees in limbo face challenging circumstances. Every day, refugees must negotiate a new culture with a hard journey behind them and a hard journey ahead. There is much that can be done to ease the plight of refugees in Canada. Of greatest importance is to grant permanent resident status simultaneously with Convention refugee status at the Immigration and Refugee Board hearing. The first step for this becoming a reality is to understand the consequences limbo places on Canada and refugees. This research starts to take us there.

\section{Notes}

1. Names have been changed to protect individuals.

2. Interview, by T. Coates, Toronto, Ontario, July 16, 2003.

3. Citizenship and Immigration Canada (2004).

4. The figure of eighteen months is based on interviews with refugee-serving agencies and refugees in limbo. It was the consensus that, with the backlog of cases, eighteen months is the fastest one could pass through the system. A faster processing time was never conveyed by any of the agencies with which we spoke.

5. IRPA, s. 55 .

6. J. Bissett, "Canada's Asylum System: A Threat to American Security?" (Washington, D.C.: Center for Immigration Studies, 2002), online: <http://www.cis.org/articles/2002/back402. html $>$ (date accessed: May 18, 2004).

7. D. Stoffman, Who Gets In: What's Wrong with Canada's Immigration Program and How to Fix It (Toronto: Macfarlane, Walter and Ross, 2002), 54.

8. Ibid., 59, quoting Mark Krikorian.

9. This study was done under the old system, in which undocumented refugee claimants were grouped as Undocumented Convention Refugee in Canada Class (UCRCC). Such a class no longer exists.

10. T.K. Gussman Associates Inc., Summary Assessment of the Undocumented Convention Refugee in Canada Class, Draft Report, 2001. 
11. H. Adelman, "Refugees and Border Security Post September 11," Refuge: Canada's Periodical on Refugees 2, no. 4 (2002): 5-14.

12. Summary of the refugee determination process is taken from the Canadian Council for Refugees, "State of Refugees in Canada," 2002, online: <http://www.web.net/ ccr/state.html> (date accessed: May 18, 2004).

13. Canadian Council for Refugees, "Refugees in Limbo: A Human Rights Issue," 1999, online: <http://www.web.net/\%7Eccr/ limbo.htm> (date accessed: May 18, 2004).

14. The Citizenship Act, s. 10 and IRPA, s. 44, 45, 46, 109. For a more complete discussion, see Andrew Brouwer's article, "Permanent Protection: Why Canada Should Grant Permanent Residence Automatically to Recognized Refugees," in this issue of Refuge.

15. For a more in-depth discussion of the field of economics and refugee policies, see D. Fisher, S. Martin, and A. Schoenholtz, "Impact of Asylum on Receiving Countries," Discussion Paper 2003/24 (Helsinki: United Nations University, World Institute for Development Economics Research, 2003).

16. Ibid.

17. "Trends in Immigration and Economic Consequences," Working Paper No. 284 (Organisation for Economic Co-operation and Development, 2001).

18. Refugees accepted in 2001 (both inland and sponsored overseas) amounted to 0.09 per cent of the Canadian population. Numbers are from Citizenship and Immigration Canada and Statistics Canada.

19. Supra note 15.

20. Ibid., 3.

21. H.S. Mohamed and A. Hashi, Beyond Settlement: Economic and Occupational Adjustment of the Somalis in the Ottawa-Carleton Region: Report of the Task Force on Employment Project for the Somali Community (1998).

22. M. Dorais, "Immigration and Integration through a Social Cohesion Perspective," Horizons 5, no. 2 (2002): 4-5.

23. In Canada, only protected persons have a Social Insurance Number (SIN) beginning with "9." An individual's SIN is required for, among other things, employment, health, and social assistance purposes.

24. Supra note 22.

25. H. Krahn, T. Derwing, M. Mulder, and L. Wilkinson, "Educated and Underemployed: Refugee Integration into the Canadian Labour Force," Journal of International Migration and Integration 1, no.1 (2000): 59-84.

26. Ibid., 72.

27. M. Beiser, "After the Door Has Been Opened: The Mental Health of Immigrants and Refugees in Canada," in The International Refugee Crisis: British and Canadian Responses (London: MacMillan, 1993), 213-27.

28. A. Ferrino, letter to the editor, "Re: Who Will Take Care of Our Children?" Toronto Star, August 10, 2003.

29. Interview, by T. Coates, Toronto, Ontario, July 15, 2003.

30. "Q \& A: Resettlement Issues of Immigrants and Refugees," Journal of Addiction and Mental Health 4, no. 6 (2001): 13.
31. Supra. note 27 at 217.

32. Ibid., 217-21.

33. Supra note 13.

34. A. K. Sen, Development as Freedom (London: Oxford University Press, 1999), 52.

35. M. Bloom and M. Grant, Brain Gain: The Economic Benefits of Recognizing Learning and Learning Credentials in Canada (Ottawa: Conference Board of Canada, 2001).

36. In Canada as of 2003, there are 22,532 working age (18-55) Convention refugees. By Canadian labour force measures, 11,376 would be working full-time, 2,641 would be working part-time and 1,171 would be unemployed.

37. T. Coates and C. Pullenayegem, "Results of Convention Refugee Questionnaire" (unpublished, for the Public Justice Resource Centre, Toronto, 2003).

38. This measure is a snapshot estimate of welfare payments to convention refugees. Refugee numbers fluctuate every year and will cause this estimate to change.

39. T. Stephens and N. Joubert, "The Economic Burden of Mental Health Problems in Canada," Chronic Diseases in Canada 22, no. 1 (2001), online: <http://www.hc-sc.gc.ca/pphb-dgspsp/ publicat/cdic-mcc/22-1/index.html> (date accessed: May 18, 2004). This figure comprises direct costs of hospital, physician, and other institutional care and prescription medications. Indirect costs were made up of short-term sick days, long-term disability, and premature death.

40. A safe third country is a country through which a refugee has passed, which is also deemed safe for refugees. Under the Canada/U.S. agreement, a refugee coming from the U.S. will not be allowed protection in Canada since they can find protection in the U.S., and vice versa. Critics say that U.S. regulations are more severe than Canada's and, if implemented, Canada's regulations would most likely move closer to those of the U.S.

41. L. Carter, "Canada's Refugee Policies in Flux," BBC News, July 21, 2003; online: <http://news.bbc.co.uk/1/hi/world/americas/ 3078743.stm> (date accessed: May 18, 2004).

42. Supra note 7 at 164 .

Tim Coates conducted research into the economic impact of refugees in limbo for Citizens for Public Justice during the summer of 2003, and is a graduate of the Economics program at St. Thomas University in New Brunswick.

Caitlin Hayward is currently working on refugee issues at Citizens for Public Justice in Toronto. She is a graduate of Mount Allison University and Queen's University Belfast.

(C) Tim Coates and Caitlin Hayward, 2005. This open-access work is licensed under a Creative Commons Attribution-NonCommercial 4.0 International License, which permits use, reproduction and distribution in any medium for non-commercial purposes, provided the original author(s) are credited and the original publication in Refuge: Canada's Journal on Refugees is cited. 